\title{
MIR150 wt Allele
}

National Cancer Institute

\section{Source}

National Cancer Institute. MIR150 wt Allele. NCI Thesaurus. Code C105986.

Human MIR150 wild-type allele is located in the vicinity of $19 q 13.33$ and is 84 bases in length. This allele, which encodes MIR150 pre-miRNA, may play a role in the regulation of gene transcription. 